\title{
The hauntological imaginary in Bernadine Evaristo's Soul Tourists (2005)
}

\section{Polo B. Moji}

Polo Belina Moji is Senior Lecturer in English literature at the University of Cape Town. Her current research focuses on Francophone Afro-European literary and cultural production.

Email: polo.moji@uct.ac.za

ORCID: https://orcid.org/0000-0002-9109-3075

DOI 10.17159/2309-9070/tvl.v.56i1.6268

\section{The hauntological imaginary in Bernadine Evaristo's Soul Tourists (2005)}

This article examines the novel, Soul Tourists (2005), by Bernadine Evaristo, a black British writer of Nigerian and English descent, through the notion of hauntology. Based on the author's assertion that "her preoccupation is her DNA," I explore the novel's depiction of a black British couple — Stanley and Jessie — as they take a road trip across Europe, and the haunting of Stanley by the ghosts of black historical figures along the way. I draw on Avery Gordon's framing of hauntology as both a racialized experience of invisible power structures of oppressions and a call to action. I firstly consider Stanley and Jessie's personal histories as haunted sites of melancholia and repressed memories. I further link hauntology to the imbrication of spiritual and physical worlds through an analysis of the erased historical figures — ghosts — that speak to Stanley at various locations along their journey. Over and above the spatiotemporal (re)mapping of blackness in Europe and the challenge to the ontological definition of Europe as 'being' a space of whiteness, I relate the hauntological imaginary to a schema of black ancestry. Keywords: Black Britain, hauntology, Bernadine Evaristo, Soul Tourists, ancestors, kinship.

\section{Introduction}

In European Others: Queering Ethnicity in Postnational Europe, Fatima El Tayeb associates European space with the myth of "colour-blindness" and the "silent racializations" of minorities (El-Tayeb xvii). In Britain, this is inflected by the political legacy of the Brixton riots of the 1980s, where a combination of high unemployment, racial tensions, and aggressive urban policing led to violent confrontations between black communities and the authorities, and the prominence of black British identity politics. Of the 1980s generation of black British cultural scholars, Paul Gilroy's There Ain't No Black in the Union Jack: The Cultural Practices of Race and Nation (1987) questions the ideological construction of the British nation as white. His subsequent work, After Empire: Melancholia or Convivial Culture? (2004), reflects on Britain's melancholic longing for a hegemonic cultural past: "the life of the nation has been dominated by an inability even to face, never mind actually mourn, the profound change in circumstances and moods that followed the end of the Empire and consequent loss of imperial prestige" (Gilroy 98). I associate this "loss of imperial prestige" with a 
veiled longing for a 'white' national space. In the current 'Brexit era,' precipitated by the 23 June 2016 popular vote to exit the European Union, black British identity politics have had to contend with the racialized discourse of 'migrant crises,' as well as the significant reversal of citizenship rights marked by the 2018 Windrush Scandal which exposed unethical deportations of and denial of social services to the Windrush generation-Caribbean migrants who had been encouraged to emigrate to Britain post World War II (1948-1971).

Bernadine Evaristo, a writer who identifies herself as being of Nigerian and English descent (Evaristo, "Official Website"), articulates a literary vision that engages with both Gilroy's observation of Britain's melancholia for a homogenous past, as well as its racial amnesia. Disguised as color-blindness, racial amnesia is an active process that erases the historical imbrication of Africa and its diaspora with Britain and Europe. The warped temporality created by the rising discourse of 'migrant crisis' since the 1990s locks the ethnic diversity (or 'browning') of the continent-through migration from Africa and the Middle East-in the present of apocalyptic near-future, ignoring the waves of migration that have shaped European history. In this regard, El Tayeb (xx) offers insight, "[The] active process of 'forgetting' [that] means that every acknowledgment of a non-white presence always seems to happen for the very first time $[\ldots]$ signifying a threatening state of exception". For Evaristo, this wilful amnesia of African history in a European context is also linked to her bi-racial identity:

I think that being English, bi-racial, and having grown up with both my parents, has in fact informed the greater project of my writing. The division between black and white is more nebulous when you are the product of an inter-racial marriage [...] but I am deeply interested in the connection between Africa and Europe and this is a dominant feature in my writing. I have thus far interrogated African history within a European/ Western context, and also the past with the present, never one to the exclusion of the other. My preoccupations are in my DNA. (Collins and Evaristo 1203)

When Evaristo articulates a preoccupation with her DNA, she evokes the histories of black mobility associated with slavery and colonization (Empire), as well as the transnational affiliations created by her African and European ancestry. As Pilar Cuder-Domínguez (176-7) quite rightly points out, Evaristo's conception of her biracial identity is further nuanced with her acknowledgment of her mother's mixed Irish-German 'whiteness,' as well as her father's Nigerian-and former Brazilian slave-ancestry. Evaristo's novel-with-verse, Soul Tourists, which depicts the European road-trip of black Britons-Stanley, of Caribbean descent, and his girlfriend Jessie, of bi-racial Yorkshire and Ghanaian descent-reflects the author's stated preoccupation with the past and present of African presence in Europe. The author herself presents Soul Tourists as "a road journey [that is] also about ghosts of color in European history who come into their lives along the way" (Muñoz-Valdivieso and 
Evaristo). These assertions facilitate an analytical approach that explicitly addresses the negotiation of race-blackness as a signifier for diverse African and Afrodiasporic identities-hidden by the language of multiculturalism and pluricultural diversity.

Soul Tourists depicts Stanley as a character who is haunted by the ghosts of black historical figures who have been erased from official accounts of European history. Starting with Lucy-a black Clerkenwell sex worker who is said to have inspired William Shakespeare (1564-1616) - the novel comes full circle when the ghost of Queen Charlotte of England, whose personal physician described her as having a "true mulatto face" (Evaristo, Soul Tourists 287), goes in search of Stanley in the novel's epilogue. I draw upon Jacques Derrida's (202) conception of hauntology in this study, starting with the assertion that it stretches our understanding of ontology (being): "To haunt does not mean to be present, and it is necessary to introduce haunting into the very construction of a concept. Of every concept, beginning with the concepts of being and time. That is what we would be calling here a hauntology." If the very 'being' of Britain and Europe is implicitly conceived of as normatively white and monocultural by the failure to 'see' or remember race (color-blindness), then hauntology—informed by the author's preoccupation with her African history in Europe-necessarily raises the challenge of remembering race, blackness, and multiculture. It is this that informs my approach to the hauntological imaginary in Soul Tourists and the framing of black (in)visibility and (un)belonging as ghostly.

\section{Evaristo's hauntological imaginary}

This study relates the genesis of Evaristo's hauntological imaginary to both her consciousness of Europe and Britain's 'racial amnesia' and myth of an inclusive multiculturalism. I see her as an archaeologist, unearthing histories buried in the sands of time to shed light on the lived experiences of the present. In this regard, she responds to the quarrel that black subjects are already constructed as absence, which is reinforced by their erasure from official historical accounts:

$[\ldots]$ it is not so difficult to see that any people who are not graciously permitted to amend the past, or control the often barely visible structuring forces of everyday life, or who do not even secure the moderate gains from the routine amnesia, that state of temporary memory loss that feels permanent and that we all need in order to get through the days, is bound to develop a sophisticated consciousness of ghostly haunts and is bound to call for an "official inquiry" into them. (Gordon 151)

Engaging with Gordon, I read the body of Evaristo's literary production as both a consciousness of the ghostly and a call for an 'official inquiry.' Soul Tourists is by no means the only example of the author's engagement with the entangled histories of the African and European continent (Collins and Evaristo; McLeod; MuñozValdivieso; Toplu). Indeed, Evaristo asserts that the purpose of her 2001 novel-in- 
verse, The Emperor's Babe, was "to disrupt the notion that Britain was only populated by white people until recently" (Collins and Evaristo 1200). This work's depiction of Zuleika, a heroine of Sudanese descent in Roman-era London, is described as revealing or re-vocalizing the multi-ethnic history of the British capital city (CuderDomínguez; Roynon). Similarly, Lara (1997) explores the past, but this time through the intimate chronology of the author's family history, described by the author as a "novel-in-verse of 150 pages which spanned 150 years, three continents, and seven generations" (Collins and Evaristo 1199). Fiction Unbound: Bernardine Evaristo (2011) by Sebnem Tolpu offers an analysis of this semi-autobiographical novel, which was expanded and republished in 2009. The study maps the shifts that occur between the two versions (published twelve years apart), observing how expanding the novel's depiction of the mother's mixed Irish-German heritage nuances the previous version's depiction of Britain's racial intolerance to include the cultural intolerance of other European identities (Toplu 11).

Published in 2005, Soul Tourists has been somewhat overshadowed by the critical success of Blonde Roots (2008), a satirical depiction of a racially inversed transatlantic slave trade. The latter novel's depiction of the racialized traffic of white labor has been framed as dystopian (Burkitt; Newman). Judie Newman (284) observes that Blonde Roots enters into conversation with both the Black Atlantic scholarship of Gilroy and the transatlantic affiliations of Evaristo's own ancestry: "In her African, British, and Afro-Brazilian family history Evaristo herself encapsulates the diasporic reach of the black Atlantic." While Soul Tourists does not extend its geographical scope across the Atlantic Ocean like Blonde Roots, it does expand its focus to continental Europe (McLeod; Muñoz-Valdivieso) in a manner that The Emperor's Babe and Lara do not. John McLeod (168) relates the novel's Afro-European sensibility to the author's "distinctly continental sense of cultural plurality which shifts the ground away from the more strictly national, exclusively British focus of late-twentieth century black British." Indeed, Evaristo's evolving hauntological imaginary excavates the past in a variety of ways-personal vs. historical chronologies, fictional vs. semiautobiographical narratives, inverted vs. (re)mapped mobilities-and Soul Tourists is part of a broader ontological challenge to the DNA of Europe and Britain as 'being' white and monocultural.

\section{The identity politics of hauntology}

Mark Fisher ("What Is Hauntology?" 16) notes the resurgence of the term 'hauntology' in the study of film and music: "What defined this 'hauntological' confluence more than anything else was its confrontation with a cultural impasse: the failure of the future." In many ways, Brexit signals Britain's failure to imagine a future and a longing for the past, driven by what Gilroy (97) describes as "the need to get back to the place or moment before the country lost its moral and cultural bearings [...] 
Turning back in this direction is also a turning away from the perceived dangers of pluralism and from the irreversible fact of multiculture." Indeed, claims around British sovereignty and the attendant 'hardening' of the English Channel as a border with continental Europe are not only manifestations of a longing for past, they also betray Britain's inability to project into the future. As I write this article, we see Britain teetering indecisively on the precipice of a 'no-deal' Brexit.

'Hauntology' is, therefore, not a term that is devoid of political valency at this present juncture in British and European history. In her study of the sociological imaginary of slavery, Avery Gordon (xvi) defines the "way in which abusive systems of power make themselves known and their impacts felt in everyday life." This underpins the discourse of the 'migrant crisis' and the manner in which it frames the migrant as both the racial 'Other' and a threat to European social order. To quote Katherine McKittrick (xiv), the "where" of blackness evokes a geography that "maps the ties and tensions between material and ideological dominations and oppositional spatial practices." The paradoxical complicity of anti-immigrant discourses and the myth of a 'color-blind' and normatively white Europe can be read as an abusive system of power with real-life consequences. Indeed, Theresa May's ' hostile environment,' launched during her tenure as Home Secretary in 2013, cannot be delinked from the stripping of the Afro-Caribbean Windrush generation's citizenship rights or the aggressive urban policing practices that target black Britons. However, haunting is also a site for "producing a something-to-be-done" (Gordon xvi), which I associate with the political valency of Evaristo's hauntological imaginary as a challenge to this ideological 'hardening.'

The trope of travel in Soul Tourists relates the "something to be done" with spatial binaries that are hardened by preconceptions of which bodies belong where: "If who we see is tied up with where we see [...] then the placement of subaltern bodies deceptively hardens spatial binaries, in turn suggesting that some bodies belong, some bodies do not belong, and some bodies are out of place" (McKittrick $\mathrm{xv}$ ). Stanley and Jessie's journey enables a multi-modal (re)mapping of European space that is signalled in the paratext by the cartographic 'excess' of the fifty-plus chapter headings, comprising a mixture of geographic sites (Café Italia, Soho), travel routes (The Freeway), temporal markers (Eighteenth Century Slave Market), and conceptual locations (The Room in Jessie's Head). While most studies of Soul Tourists focus their attention on the novel as bildungsroman that follows Stanley through his encounters with different ghosts along this journey, I wish to take seriously the haunting of the two protagonists-Stanley and Jessie-through their personal histories. The first part of my analysis relates haunting to melancholia-or the compulsion to repeat set patterns-through the depiction of how Stanley's parents long for 'home.' This is followed by an exploration of Jessie's memories and how running away from her past informs her compulsion to travel 
across Europe in a bid to reach Australia. I conclude my analysis with the historical imaginary of Africa in Europe through the figure of the speaking ghost as an invisible ancestral presence.

\section{Stanley: melancholia and the shipwrecked father}

In his geocritical approach to literature, Bertrand Westphal (21) highlights the fact that the literary engagement with space is also a question of form: "[O]ne often speaks of an aesthetic of the fragment, an aesthetic that mobilizes the blank spaces between paragraphs and operates on the real, material space of the page." Evaristo's earlier works, notably Lara and The Emperor's Babe, are written as novels-in-verse, or narrative poetry. Soul Tourists marks a departure from that form, with the author describing it as "a novel-with-verse, which is a novel that juxtaposes prose, poetry, script-like forms and, as it happens, other non-literary forms such as relationship described through a budget" (Collins and Evaristo 1199). This form creates a fragmented narrative structure, with over fifty chapters (many just a page or two long) signalled by chapter titles that trace Stanley's trajectory from his father's death in London (1987) to meeting Jessie at a singles bar (1988) and embarking on a road trip with her, ending with their separation and Stanley standing alone at the edge of the Kuwaiti desert. Soul Tourists is topographically marked as a narrative of dislocation and fragmented subjectivity (augmented by constant shifts in focalization), reflecting a lived experience that is disjointed.

The opening chapters of the novel depict Stanley's fractured relations with his parents, Pearline and Clasford, which I attribute to his widowed father whose melancholia permeates Stanley's conception of home. In his study of hauntology in music, Fisher notes the use of the 'crackle' to evoke the sound of a vinyl record:

"a sonic signature of hauntology: the use of crackle, [which] won't allow us to fall into the illusion of presence" (Fisher, Ghosts of My Life 18-9). We see this 'crackle' effect-a sonic and narrative disturbance-in the repetition of Pearline, the name of Stanley's deceased mother, and in the distinctive layout of the text when Stanley first enters the house where his father has moved to escape the ghost of his wife:

Pearline

Whose voice still greeted him when he returned home when he returned home at midnight from the Working Men's Club

Oh! Yu remember yu have a yard?

Pearline

who told me I'd inherited The Gift, passed down through generations of her mother's family: to see what others could not

They'll find yu in time Stanley (Evaristo, Soul Tourists 4) 
The name 'Pearline' forms a litany through its repetition-ten times over two pages $(4-5)$ in a passage characterized by a lack of punctuation. We hear Pearline's voice through the italicized words, spelt distinctively to reflect her pronunciation. Pearline may 'speak' in italics but the dissonance created by the repetition of her name is like the 'crackle' of a vinyl record-reminding us that she is not physically present. While Stanley perceives the loss of his dead mother, the parent to whom he was closest, as a ghostly presence, his father can be seen as a ghost of his former self, rendered a distant figure by the longing for 'home' despite settling in Britain.

The only son of Clasford, a qualified Caribbean chemist-turned-London-postman, Stanley is indebted to his disciplinarian father who worked hard to see his son become a university graduate and a successful banker. Titled, "The Shipwreck, 1987," the novel's first chapter depicts a decaying figure who doesn't bother to bath or clean his decaying house, literally drowning his melancholia in alcohol which is encapsulated by his accented and italicized lament, "We doan belong ina this country ... we doan belong Stanley" (19). He is a distant father figure who the dutiful Stanley depicts as being adrift: "I am no anchor; he is supposed to be mine, he is going, going [...]" (9). This metaphor of drowning is echoed in one of the last chapters, titled "The Ocean Floor," when Stanley spiritually 'finds' or reconnects with his paternal ancestor towards the end of his journey. As a symbol of his entrapment in the past, Clasford is buried in the suit bought when he first came to the country in 1965, a poignant reminder of his attachment to returning 'home' and perhaps a 'real' self as a qualified chemist. In this fantastical encounter with the paternal ancestor on the ocean floor, Stanley evokes his father's widowed, hermit-like existence in British space:

[...] never able to settle, even though your chosen

country had changed, your home remained an island

in your childhood heart [...]

This is your watery country new, Clasford, and say hello

to my new circle of acquittances hereabouts,

a body of restless beings like yourself

because you will not release me (256)

Clasford's failure to mourn the 'death' of his past self as a qualified chemist can be read as a reaction to the trauma of immigration. His longing for a past in which he was great results from Britain's own melancholic longing for the perceived 'greatness' of its imperial past. In his hermit-like existence, he is rendered invisible.

\section{Jessie: memory and the (in)visible cartographies of exclusion}

If European space invests in 'whiteness' "as a tool of differentiation between insiders and outsiders" (El-Tayeb xiv), it follows that race then supersedes citizenship as a 
marker of belonging. Jessie's lived experience is marked, from an early age, by a social exclusion that modulates her response to the questioning of her British citizenship:

That customs officer fingered my black

United Kingdom passport at length,

glancing up to compare information to person, as if he couldn't quite believe ... something

$[\ldots]$

You Jamaican? Bob Marley? I shot the sheriff,

Get up, stand up. No woman no ...

'No Jamaican' Moroccan? 'No Moroccan.'

Ah Brazilian! Pele best footballer in the world-

One thousand two hundred goals - not out!

English, I said, as if proffering a kiss. Really?

$[\ldots]$

He actually read the dammed passport,

Seeing as he'd spent ages looking at it (Evaristo, Soul Tourists 197-9)

The everyday, almost mundane, exclusions of the border locations are experienced through Jessie's voice, as the couple crosses over from European space (as defined by the European Union's border regulations) into Turkey. The above exchange with the immigration officer is presented as a series of couplets in which the Turkish border official's words are italicized. What is significant about this exchange is the official's inability to reconcile the identity represented by Jessie's British passport and the biracial person standing in front of him. The dissonance conveyed by "as if he couldn't quite believe ... something" seems all too familiar to Jessie who is reminded of a past incident in which her car had been strip searched for four hours as she tried to return to England by ferry from continental Europe. Conditioned by this expectation that her Britishness or Europeanness will be questioned because of her race, Jessie plays along with the ludicrous conjectures about her nationality, rather than asserting her citizenship rights. This internal cringe is all too familiar for black subjects, who are forced to negotiate Western borders, regardless of their citizenship status.

While critical readings of Soul Tourists (Hauthal; McLeod; Velickovic) limit their analysis of Jessie to her role as the instigator of the couple's European road-trip, I 
interpret this character as a haunted subject, running away from the ghosts of her past, a personal history marked by the absence of kin. Despite her refusal to discuss Stanley's encounters with ghost, Jessie thinks:

Got my own ghouls, Stanley, dear-

the nameless mother who shamelessly left me,

the named father who could have rescued me,

the son who selfishly deserted me- (129)

Unlike Stanley, who at least has a familial kinship structure, Jessie has always been without a sense of place or a genealogy of belonging. This can be read through Janet Carsten's notion of "relatedness." As she explains, "It is through living and consuming together in houses that people become complete persons-that is, kin" (Carsten 310). Her memories of growing up 'homeless' in an orphanage run by nuns and eventually falling pregnant as a teenager reflect the haunting absence of kinship: "Didn't even have a pair of knickers until I was sixteen" (Evaristo, Soul Tourists 109). Through the men who have left her, as well as her son Terry, who disappeared to Australia and has sent a postcard after twelve-years of silence, Jessie's placelessness motivates her imagined (virtual) re-union with her long-lost son (277). More broadly, her memories of resisting the Black Consciousness movement in her twenties, because belonging to Africa provoked more questions than answers, reflects this absence of kin: "[S] o which of its cultures, thousands of tribes and languages is mine, exactly?" (198).

It is perhaps paradoxical that it is Jessie, rather than Stanley, who articulates a political claim around black bodies belonging in Europe. As she says, "I think you'll find, Stanley, that slavery and the colonies were a pipeline of liquid fertilizer pumping away into British soil [...] Think that gives us land rights, don't you?" (51-2). One could argue that she has nothing else to hold onto. Jessie's placelessness illustrates the "unresolved social violence" to which Gordon (xvi) refers when describing haunting as "those singular yet repetitive instances when home becomes unfamiliar, when your bearings on the world lose direction, when the over-and-done-with comes alive." However, in Jessie's case, the tenuous notion of home is related to being born and raised in Yorkshire in an environment that was hostile to her very existence. As much as she claims her Yorkshire heritage, this is undercut by her social exclusion as a mixed-race orphan and a teenage mother. In many ways, Evaristo's character has never had a map or kinship structure with which to conceive of herself as a subject with a sense of 'place.' She wanders through Europe, haunted by her memories of social exclusion. In search of her bearings, Jessie is driven by an imagined reconciliation that connotes an expectation that kinship with her son will relieve her sense of unbelonging. Jessie - a character who flees the ghosts of her personal history-may indeed act as a foil for Stanley's discovery of African ghosts in European history. 
While she starts the journey with a sense of purpose, Stanley merely tags along to escape the monotony of his middle-class life. Ultimately, Jessie is merely repeating her cycle of running away from the painful memories of being without kin, while Stanley finds kin through encounters with the spiritual realm. While she is left stranded, with no real hope of reaching Australia and her only kin, Stanley's ghostly encounters symbolically reconnect him with his 'shipwrecked' paternal ancestor on the ocean floor and ultimately himself.

\section{Speaking ghosts, invisible ancestors}

Despite Pearline's reference to his "gift", suggesting that he is "wonderfully susceptible" (Evaristo, Soul Tourists 287) to the spectral, Stanley does not begin his journey with the intention of finding ghosts. Significantly, his first ghostly experience occurs only after he has opened himself up to a relationship with Jessie, outside the neat confines of his somewhat sterile life as a London banker. Much has been written about the individual ghosts that Stanley encounters (McLeod; Muñoz-Valdivieso; Toplu). However, I am more interested in the temporal layering created by the hauntological imaginary. Based on Westphal's (165) assertion that: "If [...] any human space, were a megabook or a palimpsest consisting of layers of spatialized time," I read Stanley's encounters as a process of temporal 'layering,' which shifts our spatial conception of Europe as a palimpsest, or a space in which multiple histories of race and racism are rendered visible in the present. Stanley's first ghostly encounter is with Lucy, the Clerkenwell sex worker thought to be the muse for William Shakespeare's series of "Dark Lady" sonnets (127-52). This intertextual relation is created when Stanley eavesdrops on a conversation between a "dreamy-eyed poet" called William who starts to recite the opening lines of sonnet number 130:

My mistress' eyes are nothing like the sun;

Coral is far more red than her lips' red;

If snow be white, why then her breasts are dun;

If hairs be wires, black wires grow on her head (Shakespeare qtd in Evaristo, Soul Tourists 64)

Historical facts about Lucy's presence in England integrated into the narrative- "She cannot remember much about her village on the guinea coast, or the ship Jesus of Lubeck that brought her west in 1563" (62)—bear testimony to Evaristo's meticulous historical research. Stanley passively witnesses the interaction between his first ghosts and is surprised by his ability to enter their thoughts. He is not a spectator in his next ghostly encounter with Louise Marie-Thérèse (1664-1732), daughter of the Queen of France (wife of Louis XIV), and "pretty Negro page" (98) Nabo. Marie-Thérèse unexpectedly approaches Stanley while he explores the palace of Versailles and addresses the following words directly to him: 
It is where I like to dream

Of Mother and the African dwarf Nabo-

Rumour had it, he was my father (92)

What follows is a temporal and narrative shift in which the reader is transported to the site of Marie-Thérèse's conception. We enter Nabo's thoughts as he hides under the bed listening as the King pays a conjugal visit to his wife. Nabo muses about his life as the queen's sexual plaything, remarking that he has once again escaped being put to death by hiding from the king in time. We learn that, "alas, alors," the queen falls pregnant and gives birth to a baby that has everyone gasping: "Métisse!" (Mixed-race!) (99), the child is confined to a nunnery for life and Nabo is "extinguished from l'histoire" (99). I relate this to Gordon's (8) definition of the ghost as "not simply a dead or a missing person, but a social figure, and investigating it can lead to that dense site where history and subjectivity make social life." Here, Nabo's erasure from history and the secrecy surrounding the existence of Marie-Thérèse designates a site from which to launch the "official inquiry" into the historical invisibility of African history in Europe.

It is worth reiterating here, that my conception of blackness and African ancestry encompasses the diversity of Stanley's various encounters with black, bi-racial, Arabic, and North African figures, which signal a return of social figures that have been repressed (extinguished) from history. He meets Joseph Boulogne, Chevalier de Saint-George (1745-1799), the son of a French nobleman and a freed Senegalese slave, in a Parisian café aptly called "Café des Fantômes" (115-22). Saint-George insists that his story "must begin with my islands Guadeloupe" (115) and reveals how leading singers refused to be "subjected to orders from a mulatto" (120) when Louis XVI asked him to direct an opera. The nature of these encounters is always unexpected, which I link to Derrida's (11) assertion that the apparition of the spectre raises the question of repetition: "[A] spectre is always a revenant. One cannot control its comings and goings because it begins by coming back." After an encounter with Tariq ibn Ziyad, the Muslim warrior who conquered the Hispanic Kingdom with a small army in 711, "a thin, sable coloured man" (Evaristo, Soul Tourists 156), Stanley and Jessie's car gets stuck on a snowy road in the Alps, and they are saved (according to Stanley) by Hannibal the Great, the Carthaginian general who was considered to be one of the great military leaders in history (176-81). This marks a turning point for Stanley, both in the evolution of his affinity to the spiritual world, and his growing distance from Jessie. He tries in vain to explain this interaction to her: "When he looked at me, history ceased to exist. We were in the same place" (180) but she chooses to confine her understanding of this episode to the concrete (physical) world. I read Stanley's description through that notion that "[haunting] happens when a place is stained by time, or when a particular place becomes the site for an encounter with broken 
time" (Fisher, "What is Hauntology" 19). Being helped by Hannibal transcends the separation between the invisible and the visible, or physical and spiritual realms, and frames haunting as a resistance to homogenized time and space. Therefore, this staining, or layering of space by time, resists homogenized histories of Europe as a historically homogenous space.

As Stanley becomes more attuned to "forces [...] operating in the world of the dead, invisible to the eye but still active. In this sense, the visible world of the living is closely connected to the invisible world of the dead" (Tadjo 2), he builds a stronger bridge to the spiritual realm. After the incident with Hannibal, Stanley shifts into the role of an "archaeologist" (perhaps mirroring Evaristo's own process), searching for ghosts from the past. A self- proclaimed "soul tourist" (Evaristo, Soul Tourists 187), he is pleased "[w]hen someone began to speak into his right ear, though there was no sensation of a body beside him" (155). As Stanley's skills in speaking with ghosts evolve, he delves into the stories of his interlocutors-notably, Alessandro de' Medici (1510-37), who describes the resistance to his being named Duke of Florence: "Why should it be him that muulaatoooo bastardooo?" (188). Next, Mary Seacole (1805-81), the Jamaican nurse who set up the "British Hotel" during the Crimean War, describes how Punch magazine described her as "That berry-brown face, with a kind hearts trace" (227) in a tribute to her work on the warfront. Significantly, Evaristo stages some of Stanley's encounters outside of European geographical space, stretching the continent's spatial boundaries north to Russia and south through Turkey and the Middle East, through the encounter with Abram (Ibrahim) Petrovich Hannibal (1696-1781), who was sold into slavery and brought as servant to Czar Peter and his grandson Alexander Pushkin, who wrote the book The Negro of Peter the Great in 1827 to honour his black ancestor (236). European space is thus depicted as a historically permeable and temporally stratified space, layered by the historical mobility of subjects from adjacent geographical regions.

While Jessie is left searching for her 'place,' Stanley's maps a cartography of his subjectivity through his discovery of spiritual African and Afrodiasporic kinship: "And there, the equatorial line across my stomach, the fuse wire, the flaming roads behind me, each detonation has made me, the phantoms that came to me and turned my world around" (281). African ancestry therefore actualizes Stanley's subjectivity in relation to history and the sociological imaginary, as depicted by the re-integration of his visible physical self and with his invisible ancestry which leaves him feeling "like a man" (282) at the end of the novel. His travelogue ends with the realization that he cannot return home (282), which I read more as the understanding that his previous notion of home has irrevocably changed than as the physical impossibility of return, a different iteration of "those singular yet repetitive instances when home becomes unfamiliar" (Gordon xvi). 


\section{Conclusion}

In this study of the hauntological imaginary in Soul Tourists, I have analysed both the personal histories_-hauntings — of Stanley and Jessie alongside ghosts of a repressed African history in Europe. Indeed, one can read the latter as the enactment of a call to haunt Europe with its repressed colonial and slave histories. However, reading these various iterations of haunting through the lived experiences of parental melancholia (Stanley) and an absence of kin (Jessie) relates haunting to present questions about the (un)belonging of immigrants and European subjects of African and Afrodiasporic descent. It is at this intersection of lived (physical) and psychic (spiritual) experience, that Evaristo's hauntological imaginary draws a genealogy of black (in)visibility that challenges the present "silent (and not so) silent racializations" that inflect European space and its borders at this present political moment.

\section{Acknowledgements}

I would like to acknowledge the support of the Andrew W. Mellon Foundation Research Support for Younger Scholars on the Wits Staff 2016-2017 competition year, which enabled me to complete this article.

\section{Works Cited}

Burkitt, Katharine. "Blonde Roots, Black History: History and the Form of the Slave Narrative in Bernardine Evaristo's Blonde Roots." Journal of Postcolonial Writing vol. 48, no. 4, 2012, pp. 406-17. DOI: https:// doi.org/10.1080/17449855.2011.616352.

Carsten, Janet. "The Substance of Kinship and the Heat of the Hearth: Feeding, Personhood and Relatedness among Malays in Pulau Langkaw." Kinship and Family: An Anthropological Reader. Eds. David Parkin \& Linda Stone. vol. 13, Wiley-Blackwell, 2004, pp. 309-27.

Collins, Michael \& Bernardine Evaristo. "'My Preoccupations Are in My DNA': An Interview with Bernardine Evaristo." Callaloo vol. 31, no. 4, 2008, pp. 1199-203. https://www.jstor.org/stable/27654982. Accessed 19 Feb. 2019.

Cuder-Domínguez, Pilar. "Ethnic Cartographies of London in Bernardine Evaristo and Zadie Smith." European Journal of English Studies vol. 8, no. 2, 2004, pp. 173-88. DOI: https://doi.org/10.1080/138255 7042000294710.

Derrida, Jacques. Specters of Marx: The State of the Debt, the Work of Mourning and the New International. Trans. Peggy Kamuf. Routledge, 2006.

El-Tayeb, Fatima. European Others: Queering Ethnicity in Postnational Europe. U of Minnesota P, 2011.

Evaristo, Bernardine. "Official Website." Bernadine Evaristo-Writer. https://bevaristo.com. Accessed 5 Feb. 2019. . Soul Tourists. Penguin, 2006.

Fisher, Mark. Ghosts of My Life: Writings on Depression, Hauntology and Lost Futures. John Hunt, 2014. . “What Is Hauntology?" Film Quarterly vol. 66, no. 1, 2012, pp. 16-24. DOI: https://doi.org/10.1525/ fq.2012.66.1.16.

Gilroy, Paul. After Empire: Melancholia or Convivial Culture? Routledge, 2004.

Gordon, Avery F. Ghostly Matters: Haunting and the Sociological Imagination. U of Minnesota P, 2008.

Hauthal, Janine. "Travelling with Ghosts: Europe as Imaginary Homeland in Dead Europe and Soul Tourists." Conference of the German Association of University English Teachers. Eds. Christoph Elhand, et al. 2015, pp. 37-46.

McKittrick, Katherine. Demonic Grounds: Black Women and the Cartographies of Struggle. U of Minnesota P, 2006.

McLeod, John. "Transcontinantal Shifts: Afroeurope and the Fiction of Bernadine Evaristo." Afroeuropean Configurations: Readings and Projects. Ed. Sabrina Brancato. Cambridge Scholars, 2011, pp. 168-82. 
Muñoz-Valdivieso, Sofía. "Shakespearean Intertexts and European Identities in Contemporary Black British Fiction."» Changing English vol. 19, no. 4, 2012, pp. 459-69. DOI: https://doi.org/10.1080/1358 684x.2012.736746.

Muñoz-Valdivieso, Sofia \& Bernardine Evaristo. "Interview with Bernardine Evaristo." Obsidian III vol. 5, no. 2, 2004, pp. 9-20. http://www.jstor.org/stable/44479690. Accessed 19 Feb. 2019.

Newman, Judie. "The Black Atlantic as Dystopia Bernardine Evaristo's Blonde Roots" Comparative Literature Studies vol. 49, no. 2, 2012, pp. 283-97. DOI: https://doi.org/10.5325/complitstudies.49.2.0283.

Roynon, Tessa. "Constructing Selfhood through Re-Voicing the Classical Past." Angelaki vol. 22, no. 1, 2017, pp. 137-152. DOI: https://doi.org/10.1080/0969725x.2017.1285998.

Shakespeare, William. The Complete Sonnets and Poems. Oxford U P, 2002.

Tadjo, Véronique. "Lifting the Cloak of (in)Visibility: A Writer's Perspective." Research in African Literatures vol. 44, no. 2, 2013, pp.1-7. DOI: https://doi.org/10.2979/reseafrilite.44.Toplu, Sebnem. Fiction Unbound: Bernardine Evaristo. Cambridge Scholars, 2011.

Velickovic, Vedrana. "Melancholic Travellers and the Idea of (Un)Belonging in Bernardine Evaristo's Lara and Soul Tourists." Journal of Postcolonial Writing vol. 48, no. 1, 2012, pp. 65-78. https://www.tandfonline. com/doi/abs/10.1080/17449855.2011.570498.

Westphal, Bertrand. Geocriticism: Real and Fictional Spaces. Trans. Robert T. Tally. Palgrave MacMillan, 2011. 